\title{
DEMONSTRATIIVPRONOOMENID JA -ADVERBID MÄÄRATLEJATENA. MIKS ME OLEME SIIN ILMAS, SELLES OLUKORRAS?
}

\author{
Helen Hint ${ }^{\mathrm{a}, \mathrm{b}}$, Piia Taremaa ${ }^{\mathrm{a}}$, Maria Reile ${ }^{\mathrm{a}}$, Renate Pajusalu ${ }^{\mathrm{a}}$ \\ ${ }^{a}$ Tartu Ülikool, EE \\ ${ }^{b}$ Tallinna Ülikool, EE \\ helen.hint@ut.ee
}

\begin{abstract}
Kokkuvõte. Artiklis analüüsime eesti keele demonstratiivide referentsiaalseid omadusi sellistes konstruktsioonides, kus demonstratiivid kuuluvad definiitse määratlejana nimisõnafraasi koosseisu. Otsime vastust küsimusele, mille poolest erinevad demonstratiivadverb (nt siin, seal) ning demonstratiivpronoomen (see, too), kui need esinevad määratlejana koos kohakäändes nimisõnafraasiga (vrd siin koolis ja selles koolis). Oleme püstitanud hüpoteesi, et demonstratiivadverbid seostuvad ruumitähendust väljendavate substantiividega, demonstratiivpronoomenid esinevad aga nende substantiividega, mille referent on mitteruumiline. Uurimuse andmestik pärineb 2017. aasta eesti keele ühendkorpusest, kust oleme võtnud 100 lauset iga demonstratiivi kohta igas kohakäändes, seega kokku 2400 lauset. Materjali analüüsime kvantitatiivselt (tingimuslike otsustuspuude ja juhumetsadega) ning kvalitatiivselt. Uurimuse tulemused kinnitavad, et substantiivi semantilised omadused, täpsemalt substantiivi semantiline klass ning konkreetsus, on seotud määratleja valikuga. Kohatähenduses substantiividega esineb määratlejana sagedamini demonstratiivadverb, mittekoha tähenduses substantiivide määratlejana kasutatakse aga demonstratiivpronoomenit. Mittekohta tähistavate substantiivide korral mõjutab määratleja valikut omakorda sõna konkreetsus. Seega on võimalik demonstratiivseid määratlejaid eesti keeles kasutada referenti looval viisil.
\end{abstract}

Märksõnad: demonstratiivpronoomen, demonstratiivadverb, definiitne määratleja, referents, konstruktsiooniline varieerumine, korpusanalüüs, eesti keel

DOI: https://doi.org/10.12697/jeful.2021.12.1.03

\section{Sissejuhatus}

Ruumiline mõtlemine on oluline pea kõigis inimtegevuse valdkondades. Keele abil saab väljendada mitmesuguseid ruumisuhteid: objektide kuju, nende orientatsiooni kõneleja keha suhtes, referentide suurust jms (vt nt Levinson 2003: 1). Siinses artiklis vaatleme ruumi ja keele suhteid selle kaudu, kuidas seostub ruumilisus nimisõnafraasi 
määratlejatega sellistel juhtudel, kui määratlejaks on demonstratiivpronoomen või demonstratiivadverb. Selgitame korpusandmetele toetudes, kuidas erinevad omavahel see, too, siin ja seal kohakäänetes nimisõnafraasi määratlejatena ning püüame korpusmaterjali kvalitatiivse ja kvantitatiivse analüüsi varal mõista, miks mõnikord öeldakse selles koolis, aga mõnikord hoopis siin koolis.

Erinevatele referentidele, st nii reaalses maailmas eksisteerivatele kui ka kujutletavatele isikutele, esemetele, sündmustele, nähtustele jm osutamist keelelise vahendi abil nimetatakse viitamiseks ehk referentsiks. Viitamise funktsiooni kannavad keeltes enamasti nimisõnafraasid (NP) (nt Abbott 2010, Kibrik 2011), kusjuures viitava NP tüüpe on erinevaid: täielik NP ilma määratlejata (nt maja, üritus, väike laps, hea tunne), täielik NP määratlejaga (nt see väike laps, siin majas, mingi hea tunne, üks üritus), personaalpronoomen (nt $m a$, $t a$ ), demonstratiiv (see, too, siia, sealt) või nullviitamine. Need põhimõtted peavad paika ka eesti keeles (Pajusalu 2017a). Määratleja on atribuudina NP koosseisu kuuluv asesõna, mis väljendab referendi infostaatust diskursuses (kas tegu on uue või juba tuntud referendiga) ja seoseid teiste referentidega (Pajusalu 2017b: 382). Siinses artiklis keskendume definiitsetele määratlejatele, st sellistele, mis viitavad NP koosseisus diskursuses juba tuntud, teada olevatele referentidele ${ }^{1}$. Seejuures eeldame varasematele uurimustele tuginedes (Pajusalu 1997, 2017b, Hint, Reile \& Pajusalu 2013, Taremaa 2017, Hint, Nahkola \& Pajusalu 2017, Reile jt 2019), et määratlejana toimivad eesti keeles nii demonstratiivpronoomenid kui ka -adverbid.

Demonstratiivid, nagu ka paljud muud indeksikaalsed keeleüksused, mitte ainult ei sõltu kontekstist, vaid ka loovad seda (Silverstein 1976: 34). Näiteks on Ritva Laury (1996, 1997: 139) soome demonstratiivide kohta väitnud, et nende vahel valitakse mitte niivõrd referendi objektiivsete omaduste järgi, vaid sõltuvalt sellest, kuidas referenti mõistestatakse, kas figuuri (ingl figure) või taustana (ingl ground). Eesti demonstratiivide varasema uurimise käigus (Sahkai 2003, Hint, Reile \& Pajusalu 2013) on selgunud, et demonstratiivpronoomenid ja lokatiivsed demonstratiivadverbid võivad viitamisel vastanduda: demonstratiivadverbid viitavad pigem ruumile, demonstratiivpronoomenid pigem asjadele (vt ka Pajusalu 2017a: 581). Meile teada olevalt ei ole aga seni

1 See, kuidas referent saab diskursuses tuntuks, võib olla erinev: eelnev eksplitsiitne mainimine, ümbritsev füüsiline või tekstiline kontekst jm. 
läbi viidud uurimusi, mis seda võimalikku vastandust süstemaatiliselt analüüsivad, ei tähenduse ega leviku poolest. Seega ongi siinse artikli üheks eesmärgiks kontrollida, kas varasem oletus demonstratiivadverbide ja demonstratiivpronoomenite erinevatest referentsiaalsetest funktsioonidest peab paika, st kas esmapilgul sarnastel keelenditel on tegelikus keelekasutuses erinevad kasutuskontekstid ehk kas ja kuidas sõltub määratleja valik peasõnaga viidatud referendi omadustest.

Ruumiväljendid on oma olemuselt väga skemaatilised (Talmy 2000a, Holmes \& Wolff 2013), mis võimaldab neil esineda väga erinevates tähendustes, sh abstraktsena. Samas võib selline polüseemia olla keelekasutuses ebamugav ja arusaamatu, nt sellel platsil võib esindada lauses ruumi või omajat. Kuna eesti keeles on võimalik kasutada määratlejana nii demonstratiivadverbi kui ka demonstratiivpronoomenit, võib oletada, et nad spetsialiseeruvad eri tähendustele. Kuna demonstratiivadverb on ka üksi esinevana oma tähenduselt oluliselt ruumilisem kui demonstratiivpronoomen (Reile jt 2019), siis on ootuspärane, et just demonstratiivadverbiga konstruktsiooni kasutatakse rohkem ruumitähendustes ja demonstratiivpronoomeniga konstruktsiooni muudes tähendustes.

Artiklis otsime vastust küsimusele, mis neid kaht määratlejaga konstruktsiooni eristab ehk millal valitakse määratlejaks demonstratiivpronoomen, millal aga demonstratiivadverb. ${ }^{2}$ Oleme varasemate uurimuste põhjal (Pajusalu 1997, Hint, Reile \& Pajusalu 2013, vt ka Sahkai 2003) püstitanud hüpoteesi, et demonstratiivadverbi kasutus on seotud ruumitähendusega, samas kui demonstratiivpronoomen esineb pigem neil juhtudel, kui nimisõna põhitähendus on seotud mitteruumilise referendiga. Näiteks on eesti keeles võimalik öelda sisekohakäänetes selles majas ja siin majas, samuti väliskohakäänetes sellel laual ja siin laual. Mõlema näite mõlemas variandis on võimalik, et kõneleja räägib ruumist, kuid demonstratiivpronoomeniga variantidel on ka teisi interpretatsioone. Võime öelda, et arhitekt pettus selles majas (aga vist mitte siin majas, vähemalt mitte samas tähenduses) ning sellel laual on neli jalga (samas tähenduses ei saa öelda siin laual). Neil konstruktsioonidel on kindlasti ka ühisjooni, nt kohakäände kasutus iseenesest konstrueerib ruumilise mõõtme, aga see võib olla pronoomeniga konstruktsioonides rohkem tagaplaanil ning adverbidega konstruktsioonides rohkem esil.

2 Siinses uurimuses jätame täiesti kõrvale küsimuse, miks määratlejat üldse kasutatakse, st mille poolest erinevad määratlejaga ja määratlejata konstruktsioon. 
Võtame oma uurimuses aluseks konstruktsioonigrammatika kognitiivse suuna, milles lähtutakse hüpoteesist, et erinevus süntaktilise vormi tasandil tingib ka konstruktsioonide tähendusliku erinevuse (Goldberg 1995: 3). Teisisõnu, eri määratlejaga konstruktsioonidel (vrd selles majas ja siin majas) on tõenäoliselt tähenduslik erinevus. Konstruktsioonigrammatikal on erinevaid lähenemisi (vt ülevaadet Hoffmann \& Trousdale 2013), kuid oma uurimust ei seo me ühegi konkreetse suunaga, vaid tugineme sellele, mis on neil ühist: konstruktsioonid on keele tähendusüksused ja nad on omavahel hierarhilises seoses (Goldberg 1995: 67-100, Taylor 1995: 197-201, Croft \& Cruse 2004: 257-290, Boas 2013). Konstruktsioonigrammatika põhiüksuseks peetakse konstruktsiooni ehk mistahes grammatilise vormi ja selle tähenduse kooslust (Goldberg 1995), kusjuures konstruktsioonid moodustavad hierarhiad, kus kõrgema tasandi üldisemad konstruktsioonid jagunevad spetsiifilisema tähendusega alamkonstruktsioonideks (Croft \& Cruse 2004).

Nähtust, kui keeles esineb mitu konstruktsiooni, millel on lähedane tähendus ning mis on üksteisega asendatavad, on nimetatud grammatiliseks, täpsemalt süntaktiliseks (lähi)sünonüümiaks (vt nt Klavan 2012, Glynn \& Robinson 2014) või ka konstruktsiooniliseks vahelduseks (ingl alternation) (nt Arppe 2009, vt ka ülevaadet Gries 2017). Konstruktsioonilist vaheldust eesti keeles on varem uuritud eelkõige kas eri käändevormide või käände ja kaassõna kasutuse vaatepunktist (Klavan 2012, Klavan, Pilvik \& Uiboaed 2015, Ruutma jt 2016, Klavan \& Veismann 2017, Siiman 2018). Näiteks on Jane Klavan ja Ann Veismann (2017) uurinud adessiivi käände ja kaassõna peal kasutust (seda nii korpus- kui ka katseandmete põhjal). Ann Siiman (2018) on omakorda näidanud illatiivi ning aditiivi alternatsiooni.

Siinses uurimuses vaadeldavaid konstruktsioone ei saa rangelt võttes pidada lähisünonüümseteks ning nende vaheldumist ei oleks korrektne nimetada konstruktsiooniliseks vahelduseks, kuna teatud kontekstides ei ole need konstruktsioonid vahetatavad (vrd arhitekt pettus selles majas ja arhitekt pettus siin majas). Siiski on aga demonstratiivpronoomenist või demonstratiivadverbist määratlejaga konstruktsioonid sarnase tähendusega ja sageli üksteisega asendatavad. Seetõttu eelistame kasutada laiemat terminit konstruktsiooniline varieerumine, mille all peame silmas olukorda, kus keeles esineb kaks või enam väga lähedase tähendusega konstruktsiooni, kuid millel võivad esineda teatud piirangud vastastikuse asendatavuse osas. Leiame, et siin käsitletav varieerumine 
sarnaneb olemuselt näiteks eesti keele lühikese sisseütleva (aditiivi) ja pika sisseütleva vaheldumisega (vt ka Siiman 2019). Kui võrrelda fraasi laps kukkus jõkke fraasiga laps kukkus jõesse, siis ilmselt eelistab emakeelne kõneleja tugevalt esimest konstruktsiooni. Pika või lühikese käändevormi valikul võib oluline roll olla näiteks konstruktsioonis esineval verbil, nt läheb kinno ja suhtub kinosse. Siiski ei ole korrektne öelda, et pika või lühikese sisseütleva vormi kasutus ühes või teises konstruktsioonis oleks täiesti ebagrammatiline. Ka siinses töös analüüsitavates konstruktsioonides avaldub teatud kontekstides tõenäoliselt tugevam eelistus ühe või teise kasuks. Hetkel puuduvad süstemaatilised uuringud, mis lubaks väita, et demonstratiivadverbiga konstruktsiooni kasutus teatud referentide puhul oleks ebagrammatiline, kuid selliseid kontekste võib olemas olla. Käesoleva uuringu eesmärk ei ole pakkuda mingit mõõdikut konstruktsiooni grammatilisuse väljaselgitamiseks, küll aga on meie töö samm selle suunas, et edaspidi saaks katseliselt uurida, millal on keelekasutajate meelest üks konstruktsioon teisega asendatav ja mida see ütleb referendi mõistestamise kohta.

\section{Vaadeldavad konstruktsioonid ja nende süntaktilised funktsioonid}

Siinses analüüsis on kõrgema tasandi konstruktsiooniks definiitne määratlejakonstruktsioon (definiitne määratleja + NP), mille keskne tähendus on referendi definiitsuse (identifitseeritavuse) väljendamine. Definiitne määratlejakonstruktsioon jaguneb järgmisel tasandil vastavalt sellele, millist tüüpi määratlejat kasutatakse (nt dem-pron + NP see maja, dem-adv + NP siin majas, omajapronoomen + NP oma maja jms). Kõik need alamkonstruktsioonid ei ole loomulikult täissünonüümid, vaid edastavad viidatu erinevaid tekstuaalseid ja informatsioonilisi aspekte. Siinses käsitluses kitsendame definiitse määratlejakonstruktsiooni alamkonstruktsioonid ühelt poolt sellega, et uurime ainult kohakäändes NP-sid, teiselt poolt sellega, et määratlejatest uurime ainult demonstratiive. Seega selgitame kasutuserinevust kahe alamkonstruktsiooni vahel: dem-pron (kohakääne) + NP (kohakääne) ja dem-adv + NP (kohakääne).

Süntaktiliselt funktsioonilt on uuritavaid fraase enamasti kirjeldatud määrustena, eelkõige koha-, sõltuvus- ja valdajamäärustena (Veismann, 
Erelt \& Metslang 2017). Sisekohakäänetes võib vormilt sama fraasi tõlgendada eelkõige kohamääruse (näide 1) või sõltuvusmäärusena (2); väliskohakäänetes aga koha- (3) või valdajamäärusena (4), harvem ka sõltuvusmäärusena (5). Määruste omavahelised piirid ei ole alati selged, nii võib näide 6 olla kas valdaja- või kohamäärus (vt Veismann, Erelt \& Metslang 2017: 328).

(1) Autod sõitsid sellesse/tollesse/siia/sinna tunnelisse. Sõbrad elasid selles/ tolles/siin/seal majas. Jooksime sellest/tollest/siit/sealt toast välja.

(2) Sõbrad suhtusid sellesse/tollesse/?siia/?sinna tunnelisse umbusuga. Probleem on selles/tolles/?siin/?seal majas. Rääkisime sellest/ tollest/?siit/?sealt toast.

(3) Sellele/tollele/siia/sinna põllule sõitsid kombainid. Sellel/tollel/siin/ seal turul on suur valik. Sellelt/tollelt/siit/sealt katuselt libises korstnapühkija alla.

(4) Sellele/tollele/?siia/?sinna põllule on meil ostja olemas. Sellel/ tollel/?siin/?seal turul on oht pankrotti minna.

(5) Sellele/tollele/siia/sinna kohale kandideeris palju noori.

(6) Sellelt/tollelt/siit/sealt katuselt viisid vargad antenni minema.

Näidetest võime intuitiivselt järeldada, et kohamääruste korral on nii pronoomeniga konstruktsioonid kui ka adverbiga konstruktsioonid tavalised ja loomulikud. Küsimusi võib tekkida seoses sõltuvus- ja valdajamäärustega, kui ei ole päris selge, kas adverbiga konstruktsioon on grammatiline või mitte. Muidugi ei ole adverbid sõltuvus- ja valdajamääruste korral nii tavalised määratlejad kui pronoomenid (näited 2 ja 4), kuid näide 5 kinnitab, et sellised kontekstid ei ole siiski võimatud. Meile teada olevalt ei ole läbi viidud (psühho)lingvistilisi uurimusi, mis oleks hinnanud seda, kui aktsepteeritavad (või grammatilised) on adverbidest määratlejad sõltuvus- ja valdajamäärustega konstruktsioonides. Me ei ole siinses uurimuses eristanud eri liiki määrusi, kuna see on korpuse materjali põhjal täie tõsikindlusega võimatu. Küll aga võib tulevikus osutuda otstarbekaks uurida määratlejate esinemust tüüpilistes sõltuvus-, valdaja- ja kohamäärustes eraldi. 


\section{Uurimismaterjal ${ }^{3}$}

Nagu eespool mainitud, siis analüüsime definiitseid määratlejakonstruktsioone, mis koosnevad määratlejast ja kohakäändes olevast substantiivist. Määratlejatest vaatleme demonstratiivadverbe (siia, siin, siit, sinna, seal, sealt) ja demonstratiivpronoomeneid (see, too). Käänetest on vaatluse all vaid eesti keele kohakäänded, st kolm sisekohaja kolm väliskohakäänet. Andmestikus on ainult pika (-sse) illatiivi konstruktsioonid; aditiiviga konstruktsioone siinses uurimuses eraldi ei ole analüüsitud. Keskendume ainsuses esinevatele, koos demonstratiiviga kahesõnalistele konstruktsioonidele. Huviorbiidis on definiitse määratlejakonstruktsiooni kahe alamkonstruktsiooni 12 eri varianti, seega on meie andmestikus kokku 24 konstruktsiooni varianti. Iga konstruktsioonivariandi kohta on Sketch Engine'i abil 2017. aasta eesti keele ühendkorpusest võetud 100 juhuslikku lauset. Kokku on andmestikus 2400 lauset, milles vaadeldavad alamkonstruktsioonid esinevad. Analüüsitavate alamkonstruktsioonide ${ }^{4}$ kõik variandid on on ülevaatlikult esitatud tabelis 1.

Tabel 1. Artiklis analüüsitavad konstruktsioonivariandid.

\begin{tabular}{|c|c|c|c|c|c|c|c|}
\hline \multirow{2}{*}{\multicolumn{2}{|c|}{$\begin{array}{l}\text { Demonst- } \\
\text { ratiiv }\end{array}$}} & \multicolumn{3}{|c|}{ Sisekohakääne } & \multicolumn{3}{|c|}{ Väliskohakääne } \\
\hline & & \multirow{2}{*}{$\begin{array}{l}\text { Illatiiv } \\
\text { sellesse } \\
\text { majasse }\end{array}$} & \multirow{2}{*}{$\begin{array}{c}\text { Inessiiv } \\
\text { selles } \\
\text { majas }\end{array}$} & \multirow{2}{*}{$\begin{array}{c}\text { Elatiiv } \\
\text { sellest } \\
\text { majast }\end{array}$} & \multirow{2}{*}{$\begin{array}{c}\text { Allatiiv } \\
\text { sellele } \\
\text { lauale }\end{array}$} & \multirow{2}{*}{$\begin{array}{c}\text { Adessiiv } \\
\text { sellel } \\
\text { laual }\end{array}$} & \multirow{2}{*}{$\begin{array}{c}\text { Ablatiiv } \\
\text { sellelt } \\
\text { laualt }\end{array}$} \\
\hline 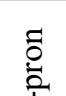 & see & & & & & & \\
\hline$\frac{1}{8}$ & too & $\begin{array}{l}\text { tollesse } \\
\text { majasse }\end{array}$ & $\begin{array}{l}\text { tolles } \\
\text { majas }\end{array}$ & $\begin{array}{l}\text { tollest } \\
\text { majast }\end{array}$ & $\begin{array}{l}\text { tollele } \\
\text { lauale }\end{array}$ & $\begin{array}{l}\text { tollel } \\
\text { laual }\end{array}$ & $\begin{array}{l}\text { tollelt } \\
\text { laualt }\end{array}$ \\
\hline \multirow{2}{*}{ 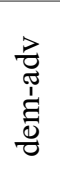 } & siin & $\begin{array}{c}\text { siia } \\
\text { majasse }\end{array}$ & $\begin{array}{c}\text { siin } \\
\text { majas }\end{array}$ & $\begin{array}{c}\text { siit } \\
\text { majast }\end{array}$ & $\begin{array}{c}\text { siia } \\
\text { lauale }\end{array}$ & $\begin{array}{c}\text { siin } \\
\text { laual }\end{array}$ & $\begin{array}{c}\text { siit } \\
\text { laualt }\end{array}$ \\
\hline & seal & $\begin{array}{c}\text { sinna } \\
\text { majasse }\end{array}$ & $\begin{array}{c}\text { seal } \\
\text { majas }\end{array}$ & $\begin{array}{c}\text { sealt } \\
\text { majast }\end{array}$ & $\begin{array}{l}\text { sinna } \\
\text { lauale }\end{array}$ & $\begin{array}{l}\text { seal } \\
\text { laual }\end{array}$ & $\begin{array}{l}\text { sealt } \\
\text { laualt }\end{array}$ \\
\hline
\end{tabular}

3 Osaliselt sama andmestikku oleme kasutatud jätku-uurimuses (Taremaa jt 2021), mille tarbeks märgendasime rohkem eri tasandite tunnuseid ja milles vaatlesime kahe alamkonstruktsiooni profiile laiemalt. Käesolevas uurimuses on fookus vaid kohatähendustel ning lisaks kvantitatiivsele analüüsile on siin esitatud ka põhjalik kvalitatiivne analüüs. Taremaa jt (2021) uurimus on tunnuste valiku poolest ulatuslikum, kuid selles ei pakuta konkreetsete keelenäidete võimalikke seletusi.

4 Lugemise lihtsustamise huvides räägime edasises tekstis neid alamkonstruktsioone nimetades lihtsalt konstruktsioonidest. 
86 Helen Hint, Piia Taremaa, Maria Reile, Renate Pajusalu

\subsection{Sagedus}

Uuritavate alamkonstruktsioonide variantide üldine esinemissagedus korpuses erineb omavahel olulisel määral (joonis 1). Väga sagedased on variandid demonstratiivpronoomeniga see, eriti allatiivis, adessiivis, inessiivis ja elatiivis, peegeldades määratleja see kasutatavust väga paljudes kontekstides. Suurema sagedusega on ka adverbiga alamkonstruktsioonid lokatiivses sisekohakäändes, st siin ja seal koos inessiivis substantiiviga. Too-ga variandid on harvad, nagu ka mõni adverbiga variant, nt siit elatiivis substantiiviga ja sealt ablatiivis substantiiviga. Siinse uurimuse eesmärk ei ole selgitada uuritavate konstruktsioonivariantide sageduserinevuste põhjuseid, vaid analüüsida nende funktsioone nende semantilistest tunnustest lähtuvalt.

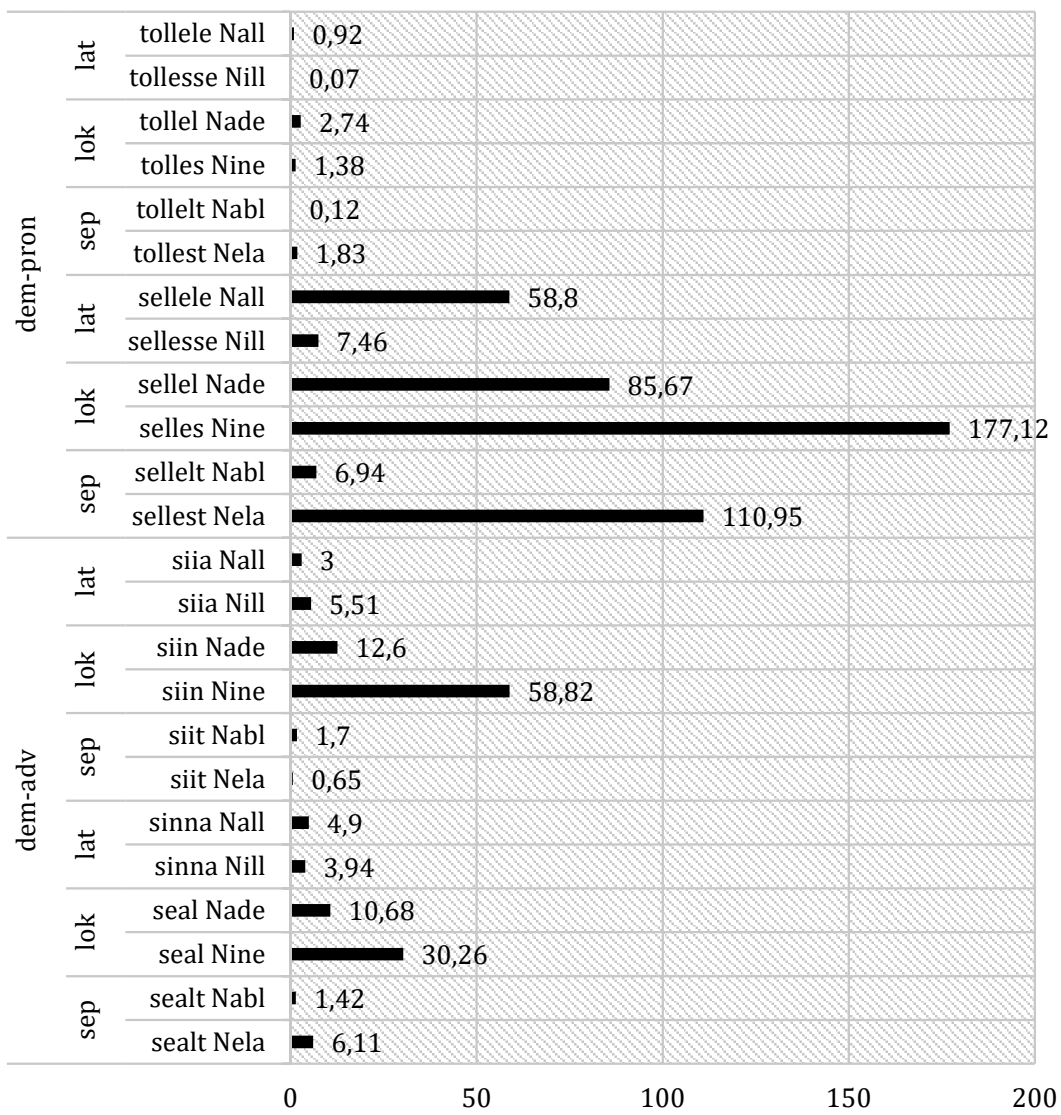

Joonis 1. Uuritavate kahesõnaliste konstruktsioonivariantide sagedus (miljoni sõna kohta) 2017. aasta eesti keele ühendkorpuses. 


\subsection{Uuritavad tunnused}

Andmestiku märgendamisel kodeerisime järgnevaid tunnuseid: substantiivi semantiline klass, substantiivi konkreetsus ning alamkonstruktsiooniga samas klausis esineva verbi tüüp. Uuritavate tunnuste valiku määras siinse artikli fookus, st keskendumine koha ja mittekoha vastandusele, mistõttu valisime tunnused, mis on selgelt ruumilise tähendusega seotud. ${ }^{5}$

Semantilise klassi kodeerimisel jaotasime fraasi peasõnana esinenud substantiivid kolme suuremasse rühma. Esimesse rühma (mittekoht) kuuluvad substantiivid, mis emakeelse kõneleja hinnangul ei väljenda prototüüpsel kasutusel ruumi, ehk elusolendile, inimeste ühendusele ja ajale viitava peasõnaga fraasid. Teise rühma (koht) kuuluvad substantiivid, mis prototüüpsel kasutusel väljendavad ruumi, st ehitised ja kohad. Kolmas rühm on n-ö segakategooria, millesse kuuluvad sõnad on ruumilisuse seisukohast polüseemsed. Sellesse rühma kuuluvad substantiivid võivad sõltuvalt kontekstist väljendada nii kohta kui ka mittekohta (asjad, institutsiooni tähistavad ehitised, sündmused, tekstid / tekstilised keskkonnad ja muud), seega meie hinnangul ei ole ühe tähenduse väljatoomine ruumilisuse seisukohast nende sõnade puhul võimalik. Enamasti on tegemist regulaarse polüseemia juhtumitega, milles üheks võimalikuks tähenduseks on koht (Langemets 2009: 112115, 137, 143-146, Veismann, Erelt \& Metslang 2017: 327)6. Näiteks substantiivi voodi, mille tähendus EKSSi järgi on magamiseks mõeldud mööbliese, võib mõista kui kohta (jään terveks päevaks siia voodisse), aga ka kui eset, mida inimene saab manipuleerida (pane sellele voodile päevatekk peale). Juhul kui sõna semantilise klassi määramine osutus keeruliseks, arutasime sõna võimalikud tähendused uurimisrühmas läbi ning lähtusime nelja emakeelse kõneleja kokkuleppelisest hinnangust.

Substantiivi semantilise klassi määramisel lähtusime vaid konstruktsioonis esineva nimisõna kontekstivabast tähendusest. Konstruktsiooni määratlejat me substantiivide semantilistesse klassidesse jagamisel ei arvestanud, kuna see oleks kaasa toonud ringargumentatsiooni, eriti

5 Põhjalikum ülevaade sellest, kuidas muud, ruumiga mitte otseselt seotud tunnused (nt elusus, liikuvus, suurus, tekstiliik jm) demonstratiivse määratleja valikut mõjutavad, on esitatud Taremaa jt (2021).

6 Margit Langemetsa (2009) käsitluses esitatud regulaarse polüseemia mallidest tulid meie materjalis esile nt ese-koht, koht_hoone-asutus, koht-grp_inimene jm. 
segakategooria puhul, kus on võimalik nii ruumina kui ka mitteruumina mõistestamine. Näiteks peasõna maja sisaldavad NP-d on märgendatud ruumina olenemata sellest, kas see esineb koos demonstratiivadverbiga (nt seal majas) või demonstratiivpronoomeniga (nt selles majas); peasõna teater, mida on võimalik tõlgendada nii ruumi kui ka institutsioonina, määrasime segakategooriasse, isegi kui selle tõlgendamine ruumina näiks igati õigustatud (nt seal teatris on 700 istekohta). Sellist märgendamissüsteemi kasutades väldime ohtu, et tõlgendame konstruktsiooni mõistestamist ruumina pelgalt selle alusel, et see esineb koos adverbilise määratlejaga, või mitteruumina seetõttu, et see esineb koos pronominaalse määratlejaga.

Andmestikus esinevad substantiivi semantilised klassid ja vastavad näited on ülevaatlikult esitatud tabelis 2 .

Tabel 2. Andmestikus märgendatud substantiivide semantilised klassid.

\begin{tabular}{l|l|l}
\hline $\begin{array}{l}\text { Mittekoht } \\
\text { (ei väljenda ruumi) }\end{array}$ & $\begin{array}{l}\text { Koht } \\
\text { (väljendab ruumi) }\end{array}$ & Segakategooria \\
\hline $\begin{array}{l}\text { aeg (nt aasta, õhtu, } \\
\text { periood) }\end{array}$ & $\begin{array}{l}\text { ehitis (nt maja, } \\
\text { katedraal, hoone) }\end{array}$ & $\begin{array}{l}\text { institutsiooni tähistav ehitis } \\
\text { (nt kool, teater, } \text { hullumaja) }\end{array}$ \\
\hline $\begin{array}{l}\text { elusolend (nt inimene, } \\
\text { arst, koletis) }\end{array}$ & $\begin{array}{l}\text { koht (nt piirkond, } \\
\text { planeet, } \\
\text { Maarjamaa) }\end{array}$ & asi (nt auto, laud, kott) \\
\hline $\begin{array}{l}\text { inimeste ühendus } \\
\text { (nt rahvas, volikogu, } \\
\text { lollikari) }\end{array}$ & & $\begin{array}{l}\text { muu (nt amet, veendumus, } \\
\text { informatsioon) }\end{array}$ \\
\cline { 3 - 3 } & $\begin{array}{l}\text { sündmus (nt } \text { kontsert, } \\
\text { koolitus, miiting) }\end{array}$ \\
& & $\begin{array}{l}\text { tekst / tekstiline keskkond } \\
\text { (nt blogi, eelnõ }, \text { veebileht) }\end{array}$ \\
\hline
\end{tabular}

Konkreetsust hindasime viitava NP peasõna kontekstivaba tähenduse järgi binaarsel skaalal: konkreetne või abstraktne. Lugesime konkreetseteks peasõnad, mis oma kontekstivaba tähenduse järgi on 1) käega katsutavad (nt kassett, rong, aadlik ja poiss); 2) silmaga nähtavad (nt koduleht, artikkel, teema (mõnes foorumis)); 3) kindla alguse ja lõpuga üritused/sündmused (nt kontsert, maraton ja reis). Abstraktseteks liigitasime 1) kõik ajaväljendid (nt päev, nädal ja öö); 2) silmale nähtamatud ja käega katsumatud referendid (nt saladus, idee, tehnika ja valdkond).

Verbi semantilist tüüpi märgendades vaatasime, mis verbi juurde määratlejaga NP kuulub - kas tegu on liikumisverbiga või mitte. 
Kuna liikumisverbide tähendused on seotud ruumiga, oletame, et kui klausis esineb liikumisverb, on sellega seotud kohakäänetes määrused mõistestatud kohana. Liikumisverbina käsitlesime verbe, mis väljendavad selgelt liikumist (nt jooksma) või paiknemist (nt seisma) või kui EKSS-is oli verbi üheks tähenduseks märgitud liikumistähendus. Paiknemisverbide liikumisverbideks määramisel lähtusime Leonard Talmy käsitlusest, mille järgi paiknemisverbid väljendavad potentsiaalset liikumist (Talmy 2000b: 25). Ühtlasi teenis see otsus siinse uurimuse eesmärki eristada ruumi tähendusega seonduvaid verbe teistest verbidest. Mitmesõnalise öeldise määrasime liikumiskonstruktsiooniks, kui see sisaldas liikumisverbi (nt hakkab ära minema) või andis kogu ühend kokku liikumistähenduse (nt laseb jalga). Kui verb ei olnud selgelt liikumisverbiks määratletav, lugesime selle mitteliikumisverbiks. Iseseisva öeldisena esineva olema-verbi kodeerisime samuti mitteliikumisverbina. Teatud juhtudel verb puudus, sel juhul kannab lause märgendit ,verb puudub“.

\section{Uurimismeetod}

Meie andmestik on olemuselt multivariatiivne ning vaadeldavad tunnused on kategoriaalsed. Seega oleme kvantitatiivseks analüüsiks valinud kaks mitteparameetrilist meetodit: kasutame tingimuslikku rekursiivset otsustuspuud ehk klassifitseerimispuud (Hothorn, Hornik \& Zeileis 2006) ja tingimuslikku juhumetsa (Breiman 2001, Strobl jt 2008, Strobl, Malley \& Tutz 2009). Tingimusliku otsustuspuu ja juhumetsa analüüsi läbiviimiseks oleme kasutanud vabavaralise statistikatarkvara R (R Core Team 2020) paketti party (Strobl, Hothorn \& Zeileis 2009, Hothorn jt 2021). Uuritavaks tunnuseks on sõnaliik (demonstratiivpronoomen või -adverb) ja seletavaid tunnuseid on kolm: 1) viitavas NP-s esineva substantiivi semantiline klass (SubstSemKoond ja SubstSem), 2) viitava fraasi konkreetsus ning 3) verbitüüp (liikumisverb või mitte).

Lisaks analüüsime vaadeldavaid alamkonstruktsioone sisaldavaid lauseid ka kvalitatiivselt (ptk 6). 


\section{Kvantitatiivse analüüsi tulemused}

\subsection{Materjali koondanalüüs}

Uurimismaterjali analüüsimisel vaatame esmalt seda, kas kohale (st kindlasti füüsilise ruumiga seotud substantiividega) ja mittekohale (st ruumiga kindlasti mitte seotud substantiividega) viitamisel on selgeid erinevusi keelelistes valikutes, st kas määratleja valik sõltub sellest, millisesse semantilisse klassi kuulub NP-s kasutatud substantiiv. Materjali põhjal ilmneb, et kohale viitavate substantiividega kasutatakse määratlejana pigem demonstratiivadverbi $(80,8 \%)$ ning mittekohale (st ajale ja elusolendile) viitavate substantiividega esineb määratlejana pigem demonstratiivpronoomen $(92,8 \%)$, seega uurimuses püstitatud hüpotees peab paika. Segakategoorias ei ole aga selget määratleja eelistust: demonstratiivpronoomeneid $(50,1 \%)$ ja demonstratiivadverbe $(49,9 \%)$ kasutatakse võrdse sagedusega (vt tabelit 3).

Tabel 3. Määratlejana esinevad demonstratiivid eri semantilistes kategooriates ${ }^{7}$.

\begin{tabular}{l|c|c|c}
\hline \multirow{2}{*}{$\begin{array}{l}\text { Substantiivi } \\
\text { semantiline kategooria } \\
\text { (SubstSemKoond) }\end{array}$} & \multicolumn{2}{|c|}{ Demonstratiiv } & \multirow{2}{*}{ Kokku } \\
\cline { 2 - 3 } Koht & Adverbiline & Pronominaalne & Ko5 (80,8\%) \\
\hline Mittekoht & $120(19,2 \%)$ & $625(100 \%)$ \\
\hline Segakategooria & $\mathbf{6 6 3 ( 4 9 , 9 \% )}$ & $\mathbf{4 1 5}(\mathbf{9 2 , 8 \% )}$ & $447(100 \%)$ \\
\hline Kokku & $1200(50 \%)$ & $1200(50 \%)$ & $2400(100 \%)$ \\
\hline \multicolumn{2}{l|}{$\chi^{2}=565,33 \cdot d f=2 \cdot$ Craméri $V^{8}=0,49 \cdot p<0,001$} & $1328(100 \%)$ \\
\hline
\end{tabular}

Konkreetsus on samuti oluline referentsiaalse konstruktsiooni valikuga seotud kategooria. Tabelist 4 näeme, et kui tegu on konkreetse peasõnaga, siis esineb see meie andmestikus pigem koos adverbilise määratlejaga $(60,8 \%)$. Kui tegu on abstraktse peasõnaga, siis on eelistatum pronominaalne määratleja $(84,6 \%)$. Abstraktset tähendust

7 Tabelite koostamiseks on kasutatud R-i paketti sjPlot (Lüdecke 2021).

8 Korrelatsioonikordaja Craméri V (muutub vahemikus $0 \ldots+1$ ) näitab tunnuste vahelise seose tugevust: alates 0,1 st on nõrk seos, 0,3 st keskmine seos ja 0,5 st tugev seos (Cohen 1988: 224-225). 
väljendava peasõnaga viitavaid konstruktsioone (570, s.o 24\%) on andmestikus märgatavalt vähem kui konkreetset tähendust kandva peasõnaga konstruktsioone (1830, s.o 76\%).

Tabel 4. Määratlejana esinevad demonstratiivid konkreetse ja abstraktse peasõnaga konstruktsioonides.

\begin{tabular}{l|c|c|c}
\hline \multirow{2}{*}{$\begin{array}{l}\text { Substantiivi } \\
\text { konkreetsus }\end{array}$} & \multicolumn{2}{|c|}{ Demonstratiiv } & \multirow{2}{*}{ Kokku } \\
\cline { 2 - 4 } Abstraktne & $88(15,4 \%)$ & $482(84,6 \%)$ & $570(100 \%)$ \\
\hline Konkreetne & $1112(60,8 \%)$ & $718(39,2 \%)$ & $1830(100 \%)$ \\
\hline Kokku & $1200(50 \%)$ & $1200(50 \%)$ & $2400(100 \%)$ \\
\hline$\chi^{2}=367,89 \cdot d f=2 \cdot$ Craméri $V=0,39 \cdot p<0,001$ & Pronominaalne & $p$ \\
\hline
\end{tabular}

Verbi semantilise tüübi jaotust analüüsides näeme tabelist 5 , et liikumisverbiga esinevaid konstruktsioone (464) on materjalis oluliselt vähem kui mitteliikumisverbiga esinevaid konstruktsioone (1822). Ent kui mitteliikumisverbiga samas klausis kasutatud konstruktsioonides ei ilmne kindlat määratleja eelistust (46,3\% adverbilisi ja 53,7\% pronominaalseid), siis liikumisverbide kasutussagedus oli suurem demonstratiivadverbiga konstruksioonidega $(67,9 \%$ vs. demonstratiivpronoomeniga $32,1 \%$ ).

Tabel 5. Määratlejana esinevad demonstratiivid eri verbitüübiga kasutatud konstruktsioonides.

\begin{tabular}{l|c|c|c}
\hline \multirow{2}{*}{ Liikumisverb } & \multicolumn{2}{|c|}{ Demonstratiiv } & \multirow{2}{*}{ Kokku } \\
\cline { 2 - 3 } & Adverbiline & Pronominaalne & Ki \\
\hline Jah & $844(46,3 \%)$ & $978(53,7 \%)$ & $1822(100 \%)$ \\
\hline Verb puudub & $315(67,9 \%)$ & $149(32,1 \%)$ & $464(100 \%)$ \\
\hline Kokku & $41(36 \%)$ & $73(64 \%)$ & $114(100 \%)$ \\
\hline
\end{tabular}

$\chi^{2}=78,23 \cdot d f=2 \cdot$ Craméri $V=0,18 \cdot p<0,001$

Selleks, et näha määratleja sõnaliigi, substantiivi semantilise klassi, substantiivi konkreetsuse ning verbitüübi omavahelisi seoseid, kasutame klassifitseerimispuu ja juhumetsa meetodit. 
Kolme tunnusega mudeli põhjal koostatud klassifitseerimispuu on esitatud joonisel 2 (seosekordaja $\mathrm{C}=0,8$, st tegu on tugeva mudeliga). Esimene tunnus, mis andmestikku kaheks jagab, on substantiivi semantiline klass (SubstSemKoond): kohta ja segakategooriat väljendavad substantiivid koonduvad klassifitseerimispuu vasakusse harusse ning mittekohad on esindatud paremas harus. Mittekohale viitava substantiivi määratlejana eelistatakse demonstratiivpronoomenit, kusjuures abstraktsele mittekohale viitava substantiiviga kasutatakse uurimismaterjalis alati dem-pron + NP konstruktsiooni (joonisel sõlm (Node) 17). Konkreetne mittekoht võib esineda ka dem-adv + NP konstruktsioonis, kusjuures liikumisverbiga on demonstratiivadverbi kasutus mõnevõrra tavalisem (joonisel sõlm 15) kui mitteliikumisverbiga või verbita klausides (joonisel sõlm 16).

Ulatuslikum pronoomenikasutus tuleb esile ka klassifitseerimispuu vasakpoolse haru kahes esimeses lõppsõlmes. Tegu on abstraktsesse segakategooriasse liigitatud substantiividega ning siingi selgub, et liikumisverbiga esineb adverbilisi määratlejaid rohkem (joonisel sõlm 6) kui mitteliikumisverbiga konstruktsioonides (joonisel sõlm 5).

Demonstratiivadverbid esinevad määratlejana enamasti kas koha ja segakategooria konkreetsete substantiividega (joonisel sõlm 11 ja sõlm 12) või abstraktse kohaga (joonisel sõlm 8 ja sõlm 9). Ehkki klassifitseerimispuul on välja toodud ka verbitüüp kui statistiliselt oluline kategooria, ei ole siinse analüüsi põhjal liikumis- ja mitteliikumisverbide erinevused vaadeldavate konstruktsioonide lõikes väga selged. Näeme, et teatud tingimustel esinevad liikumisverbidega sagedamini demonstratiivadverbiga konstruktsioonid kui -pronoomeniga konstruktsioonid (sõlm $8 v s$. sõlm 9 ja sõlm 15 vs. sõlm 6), kuid verbitüüp on järjekorras alles kolmas tunnus semantilise klassi ja konkreetsuse järel, mis andmestiku kaheks jagab. 


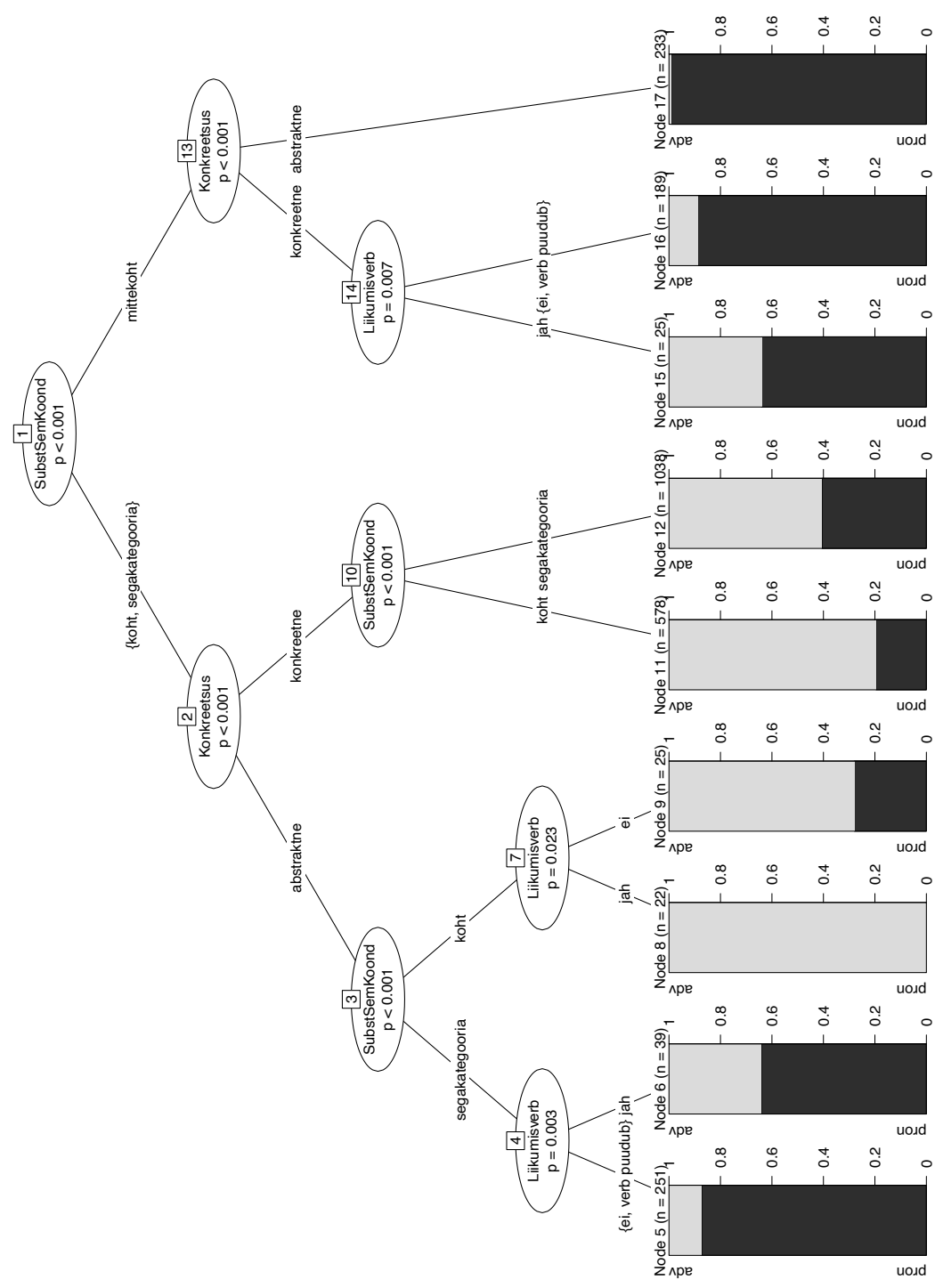

Joonis 2. Demonstratiivi valikut selgitav klassifitseerimispuu koondandmestiku substantiividega: Sõnaliik Liikumisverb + SubstSemKoond + Konkreetsus. 
Kontrollime tunnuste statistilist olulisust ka juhumetsa meetodiga (vt joonist 3). Selgub, et statistiliselt kõige olulisem tunnus on substantiivi semantiline klass, sellele järgneb NP-s esineva substantiivi konkreetsus. Verbitüüp, st kas tegu on liikumisverbiga või mitte, ei osutu statistiliselt oluliseks.

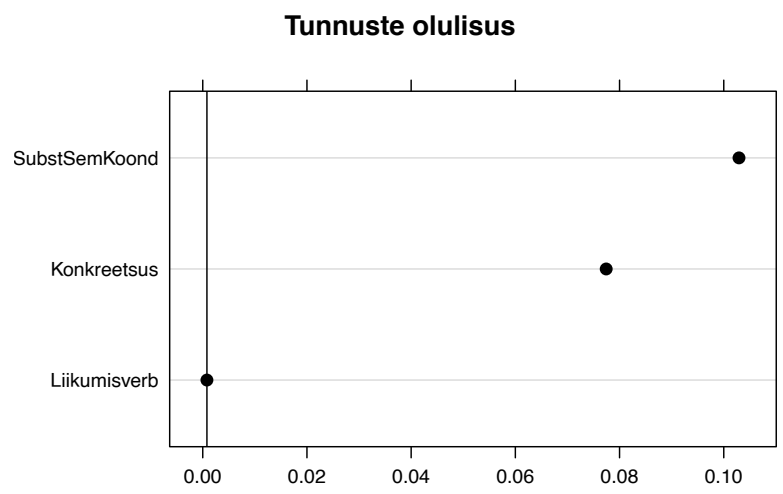

Joonis 3. Demonstratiivi valikut selgitavate tunnuste olulisus koondandmestikus (statistiliselt olulised tunnused paiknevad mustast joonest paremal).

\subsection{Segakategooria analüüs}

Semantiliselt nn segakategooriasse kuuluvate substantiividega viitamisel kasutatakse määratlejana võrdselt nii demonstratiivpronoomenit kui ka demonstratiivadverbi (vt tabelit 6). Koondmaterjali põhjal joonistatud klassifitseerimispuust näeme, et statistiliselt sarnanevad segakategooria substantiivid pigem koha kui mittekoha kategooriaga (vt joonist 2). Et aga täpsemalt näha, kas segakategooria substantiividel on kindlaid tunnuseid, mis määravad, kas eelistatud on adverbiline või pronominaalne määratleja, analüüsime klassifitseerimispuu ja juhumetsa meetodiga ka ainult segakategooria substantiive, kaasates seletavate tunnustena detailsemad semantilised klassid (SubstSem) ning konkreetsuse. Kuna verbitüüp ei osutunud koondmaterjalis statistiliselt oluliseks, siis oleme selle tunnuse edasisest analüüsist välja jätnud.

Tabelist 6 selgub, et demonstratiivadverbe eelistatakse määratlejana asjade $(59,5 \%)$, institutsioone tähistavate ehitiste $(77,4 \%)$ ning tekstide / tekstiliste keskkondade korral (68,5\%). Demonstratiivpronoomenid esinevad määratleja funktsioonis sündmusi (62,8\%) ning „,muud“ väljendavate substantiividega $(70,6 \%)$. 
Tabel 6. Määratlejana esinevad demonstratiivid substantiivide segakategooria semantilistes klassides.

\begin{tabular}{l|c|c|c}
\hline \multirow{2}{*}{$\begin{array}{l}\text { Substantiivi semantiline } \\
\text { klass (SubstSem) }\end{array}$} & \multicolumn{2}{|c|}{ Demonstratiiv } & \multirow{2}{*}{ Kokku } \\
\cline { 2 - 3 } & Adverbiline & Pronominaalne & Ksi \\
\hline institutsioon & $\mathbf{1 2 5}(\mathbf{5 9 , 5 \% )}$ & $85(40,5 \%)$ & $210(100 \%)$ \\
\hline muu & $\mathbf{2 4}(\mathbf{7 7 , 4 \% )}$ & $7(22,6 \%)$ & $31(100 \%)$ \\
\hline sündmus & $145(29,4 \%)$ & $\mathbf{3 4 8 ( 7 0 , 6 \% )}$ & $493(100 \%)$ \\
\hline tekst & $45(37,2 \%)$ & $\mathbf{7 6}(\mathbf{6 2 , 8 \% )}$ & $121(100 \%)$ \\
\hline Kokku & $\mathbf{3 2 4}(\mathbf{6 8 , 5 \% )}$ & $149(31,5 \%)$ & $473(100 \%)$ \\
\hline$\chi^{2}=173,22 \cdot d f=4 \cdot$ Craméri $V=0,361 \cdot p<0,001$ & $1328(100 \%)$ \\
\hline
\end{tabular}

Tabelis 6 välja joonistuvad rühmad avalduvad selgelt ka segakategooria substantiivide klassifitseerimispuul, mis on esitatud joonisel $4(\mathrm{C}=0,75)$. Esmatasandi jagunemine toimubki substantiivi semantilise klassi põhjal: asjad, institutsioonid ning tekstid / tekstilised keskkonnad moodustavad puu vasaku haru ning sündmused ning semantilisse klassi „muu“ kuuluvad substantiivid puu parempoolse haru. Edasi eristab demonstratiivpronoomeni või -adverbi valikut substantiivi konkreetsus. Kui tegemist on abstraktse peasõnaga, eelistatakse kasutada pronominaalset (joonisel 4 sõlm 3 ja sõlm 9), kui peasõna tähendus on konkreetne, kasutatakse rohkem adverbilist demonstratiivi. Sealjuures esinevad adverbilise määratlejaga rohkem sellised substantiivid, mis kuuluvad institutsioonide ja teksti alla (joonisel sõlm 6), aga ka asjade hulka kuuluvate substantiivide puhul on demonstratiivadverb sagedasem (joonisel sõlm 5). Ootuspäraselt ei tule selget eelistust esile konkreetsete substantiivide puhul, mis väljendavad sündmusi või semantilist klassi „muu“ (joonisel sõlm 8) - kuna „muud“ substantiivid võivad olla olemuselt väga erinevad, siis ka määratlejate funktsioonid on selles rühmas ilmselt üsna erinevad. 
96 Helen Hint, Piia Taremaa, Maria Reile, Renate Pajusalu

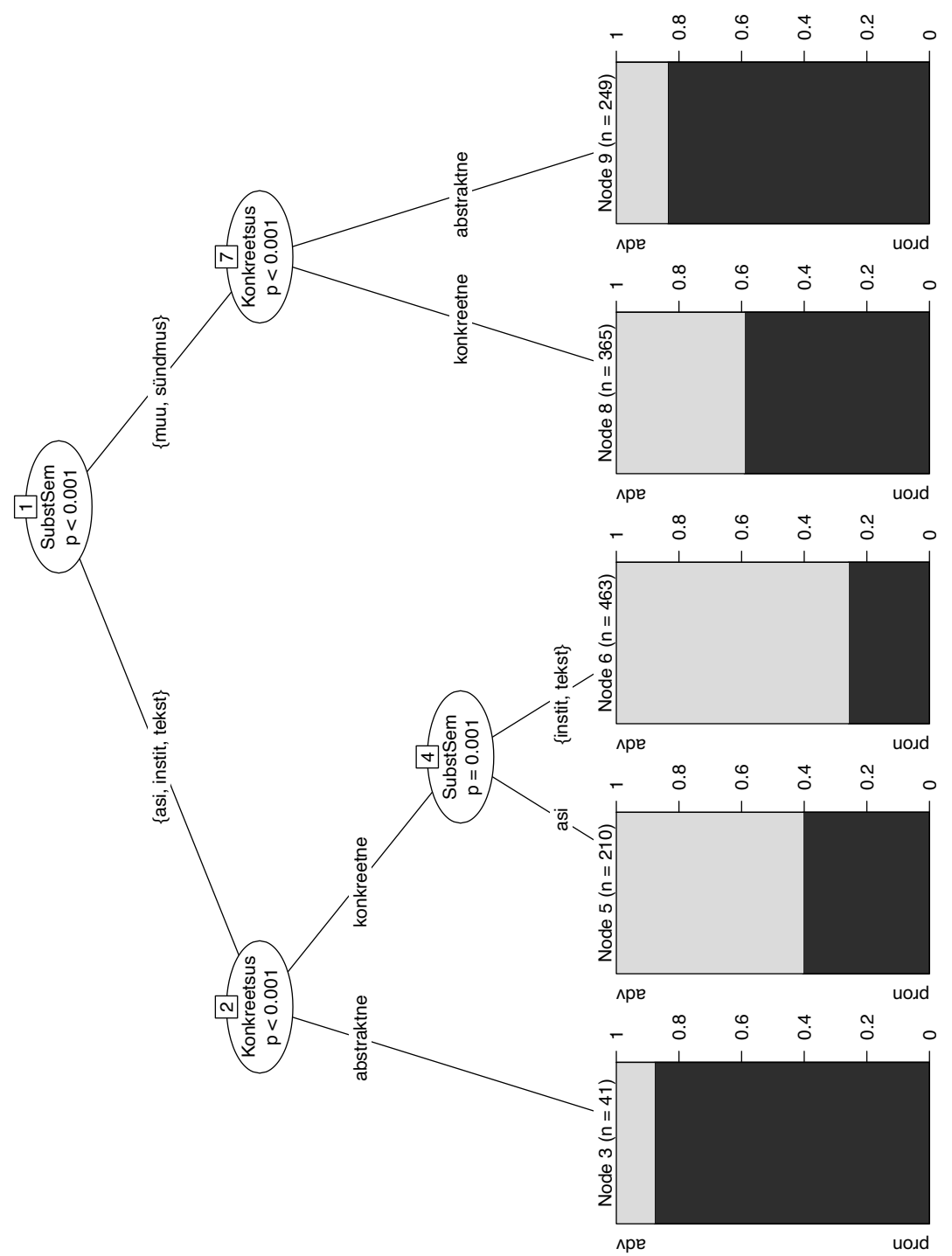

Joonis 4. Demonstratiivi valikut selgitav klassifitseerimispuu segakategooria substantiividega: Sõnaliik SubstSem + Konkreetsus. 
Segakategooria klassifitseerimispuul esitatud tunnuste statistilist olulisust hindame juhumetsa meetodiga (joonis 5). Analüüsist selgub, et statistiliselt oluline on substantiivi semantiline klass. Substantiivi konkreetsus selles semantilises kategoorias statistiliselt oluliseks ei osutu.

\section{Tunnuste olulisus}

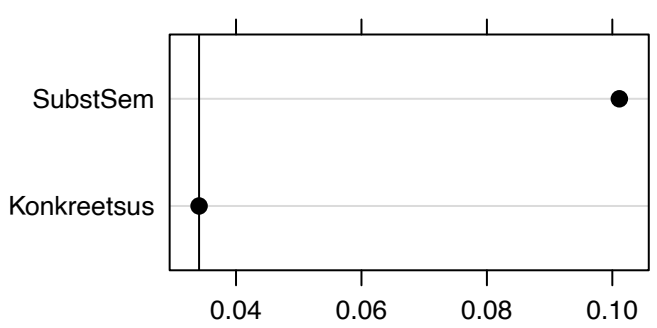

Joonis 5. Demonstratiivi valikut selgitavate tunnuste olulisus segakategooria substantiividega (statistiliselt olulised tunnused paiknevad mustast joonest paremal).

\section{Korpuslausete kvalitatiivne analüüs}

Selles peatükis esitame korpusmaterjalist pärit keelenäiteid, mis aitavad selgitada siinse uurimuse tulemusi, st mõista määratlejana esinevate demonstratiivadverbide ja demonstratiivpronoomenite kasutuserinevusi. Esmalt selgitame statistilisest analüüsist välja joonistunud üldiseid tendentse. Seejärel keskendume aga sellistele kasutusjuhtumitele, mis on meie andmestikule iseloomulikud, kuid mis statistilises analüüsis otseselt ei avaldu (nt ajaväljendite ja demonstratiivpronoomeni too seos).

\subsection{Kasutustendentsid}

Analüüsi tulemusel sai kinnitust hüpotees, et kohasõnadega kasutatakse enamasti demonstratiivadverbidest määratlejaid (7) ning mittekohasõnadega viitamisel on määratlejana kasutusel pigem demonstratiivpronoomenid (8). 
(7) Aga miks, või mis seal telemajas üldse toimub, ei saa ma aru. ${ }^{9}$ (koht, dem-adv)

(8) Oluline on see, et igaüks sellest grupist saaks oma teema. (mittekoht, dem-pron)

Siiski, esineb mõningaid juhtumeid, mil üldistus mittekoht $=$ pronoomen ja koht $=$ adverb ei pea paika. Üheks selliseks sõnaks on saar, mis, olles meie andmestikus alati kodeeritud konkreetse kohana, esineb kolmel korral koos demonstratiivpronoomeniga (9) ja kuuel korral koos -adverbiga (10). Kuna andmestikus on taolisi näiteid arvuliselt siiski vähe, siis ei ole võimalik pakkuda kindlat selgitust selle kohta, miks on üht või teist määratlejaga alamkonstruktsiooni eelistatud. Tegureid, mis võivad määrava tähtsusega olla, on mitmeid, nt olukorra reaalsus või hüpoteetilisus, deiktiline või anafooriline viitamine, kõneleja asukoht viidatava koha suhtes kõnelemise hetkel, kõneleja isiklikud kasutuseelistused vmt.

(9) ma usun, et me saaks sellelt saarelt üpris hõlpsasti põgenetud (koht, dem-pron)

(10) Päev väikses privaatrannas, oli tõeliselt lahe vaheldus igapäevaelule siin saarel (koht, dem-adv)

Abstraktsete substantiividega viitamisel esineb rohkem demonstratiivpronoomeneid $(11,12)$, konkreetsete substantiividega viitamisel kasutatakse enam aga demonstratiivadverbe (13). Abstraktsete substantiivide juures tasub tähele panna, et NP esinemine kohakäändes võib olla tingitud sellest, et tegu on rektsioonilise laiendiga, nagu näites (11), kus põhjaks olev verbiühend (lõppu peale tegema) määrab kohakäände kasutuse.

(11) „Kuulge,“ tõstsin ma lõpuks häält, otsustanud sellele jamale lõpu peale teha. (abstraktne, dem-pron)

(12) Õnneks suutsin tollelt kiiruselt kaarti käsitleda ja ei vääratanud (abstraktne, dem-pron)

9 Kõik näitelaused on esitatud korpuses esinenud originaalkujul. 
(13) loodetavasti neil seal Toompeal jätkub nii palju arukest (konkreetne, dem-adv)

Konkreetsus osutus statistilises analüüsis olulisuse järjekorras teiseks tunnuseks semantilise klassi järel. Seega tuleb arvestada sellega, et eri semantiliste klasside korral konkreetse või abstraktse põhisõnaga konstruktsioonide määratleja eelistus mõnevõrra erineb. Kohtadele viitamisel on nii abstraktse kui ka konkreetse substantiivi määratlejana kasutusel üldjuhul demonstratiivadverb. Kohad osutusid andmestikus enamasti konkreetseks (nagu näites 7 seal telemajas). Kuid esines ka juhtumeid, kus tähenduselt abstraktset sõna oli kasutatud kohale viitamiseks: näites 14 on külmetamine see, millega viidatakse metonüümiliselt kohale, kus külmetamist läbi viiakse. Demonstratiivadverbi kasutamine suunab tõlgenduse koha suunas (sellele külmetamisele oleks suunanud tõlgendust protseduuri suunas).

(14) ma proovin senikaua äädikaga vist.. ja siis arsti juurde.. tänud kõigile..ja arvatavasti saan siis saatekirja et sinna külmetamisele minna (abstraktne koht, dem-adv)

Demonstratiivadverbi kasutamise poole võib kallutada ka see, et lähedale viitav demonstratiivadverb on üsna tugevalt deiktiline, st näites (15) kasutatud fraasi siia turule tõlgendatakse tõenäoliselt 'Eesti turule'. Demonstratiivpronoomen (sellele turule) oleks selles kontekstis pigem anafooriline, st viitaks tagasi mingile tekstis eelnevalt mainitud turule.

(15) Ja see ongi see et suured välismaised kokkuostjad tulevad siia turule ja panevadki hinna paika. (abstraktne koht, dem-adv)

Mittekohale, st meie andmestikus elusolendile ja ajale viitamisel on aga abstraktse substantiivi määratlejana alati kasutatud demonstratiivpronoomenit (16), kusjuures need näited on andmestikus seotud ajaväljenditega, sest elusolendid on üldjuhul konkreetsed.

(16) kuid kasum jääb sellel aastal arvatavasti mitmetel põhjustel äärmiselt kesiseks. (abstraktne mittekoht: aeg, dem-pron) 
Ka konkreetse mittekoha korral domineerib demonstratiivpronoomeni kasutus, ehkki demonstratiivadverb ei ole sellisel juhul päris võimatu. Siiski, inimesele või teisele elusolendile kui üksikisikule viitamisel on määratlejana alati kasutusel demonstratiivpronoomen (17), samas kui demonstratiivadverbi kasutatakse andmestikus alati inimeste ühendusest rääkides (18).

(17) Teilt tuli üks informatsioon, aga tollelt ametnikult hoopis teine. (konkreetne mittekoht: elusolend, dem-pron)

(18) Kuna valitsuse poolt läheb sinna nõukogusse liikmeid nagunii, siis võiks Riigikogu esindaja tõesti olla opositsioonist. (konkreetne mittekoht: inimeste ühendus, dem-adv)

\subsection{Spetsiifilised kasutusjuhtumid}

Kui mittekohasõnaga viitamisel nägime selget demonstratiivpronoomeni eelistust ning kohasõnaga viitamisele on iseloomulikum demonstratiivadverbi kasutus, siis ambivalentsete sõnade (asi, institutsioon, sündmus, tekst / tekstiline keskkond, muu) koondarvestuses kasutatakse võrdsel hulgal mõlemat määratlejat, ehkki alamklasside sees tulevad esile selgemad määratleja eelistused välja (vt tabelit 6 peatükis 4.2). Siinse uurimuse kontekstis toetavad need üldised tulemused oletust, et määratlejad siin ja seal on seotud pigem ruumitõlgendusega, määratlejad selles ja tolles aga suunavad referenti mõistma mitteruumina. Peame seda tulemust kasulikuks eelkõige segakategooria substantiivide käsitlemisel: juhul kui viitava NP-ga seotud muud tunnused (andmestikus märgendatud liikumisverb ja konkreetsus) on samad, siis lähtuvalt määratleja valikust (demonstratiivpronoomen või -adverb) võime seletada erinevusi referendi mõistestamisel. Meie lähtekohaks on, et erinevad definiitse määratlejaga alamkonstruktsioonid ei ole sünonüümsed. Seetõttu saame oma andmestikule tuginedes kinnitada, et kui määratlejaks on demonstratiivpronoomen, siis mõistestatakse referenti pigem mittekohana, ent kui määratlejaks on demonstratiivadverb, siis mõistestatakse referenti pigem kohana. Kuigi juba varem on olnud teada, et lokatiivsed demonstratiivadverbid viitavad kohale, siis siinne uurimus on esimene, mis vaatab demonstratiivadverbide ja demonstratiivpronoomenite vastandust süstemaatiliselt ning toob lisaks välja, et on ka palju teistsuguseid kasutusi. 
Näiteks esineb substantiiv laud andmestikus määratlejaga konstruktsioonis viiel korral ning neil juhtudel on määratlejaks demonstratiivadverb (19), mis viitab sellele, et sellistes näidetes tuleks lauda mõista pigem koha kui esemena. Oleks siiski täiesti aktsepteeritav, kui laud esineks koos demonstratiivpronoomeniga, nt minu korteris ei leidu sellele lauale õiget kohta (konstrueeritud näide). Kuna demonstratiivpronoomen on omane pigem just mittekohasõnaga konstruktsioonis, siis selles konstrueeritud näites võikski lauda tõlgendada pigem mittekohana, täpsemalt manipuleeritava esemena, mille asukohta mingi (lauast suurema) ruumi kontekstis muudetakse.

(19) Usu mind, siia lauale mahub sadu muffineid (segakategooria: asi, dem-adv)

Substantiive, mida sobiks tõlgendada nii ruumilise kui ka mitteruumilisena, st millega koos võib määratleja positsioonis esineda nii demonstratiivpronoomen kui ka -adverb, esineb andmestikus mitmeid. Ühe sellise mõistelise rühma moodustavad erinevat tüüpi tekstid või tekstilised keskkonnad, kas siis füüsilise eseme kujul või mõttelise tervikliku kirjatöö vormis, nt raamat (9 korda dem-adv + NP ja 8 korda dem-pron + NP konstruktsioonis), artikkel (15 korda dem-adv + NP ja 12 korda dem-pron + NP), teema (33 korda dem-adv + NP ja 16 korda dem-pron $+\mathrm{NP})$. Sellisteski näidetes saab viitava NP mõistestamisel abiks võtta just konstruktsioonis esineva määratleja.

Segakategoorias leidub veelgi hulgaliselt substantiive, mida kasutatakse ühtviisi nii demonstratiivpronoomeni kui ka -adverbiga konstruktsioonides, nt pidu (5 dem-adv, 3 dem-pron), reis ( 3 dem-adv, 7 dem-pron), riik (8 dem-adv, 4 dem-pron), saade ( $8 \mathrm{dem}-\mathrm{adv}, 4 \mathrm{dem}$-pron), tö̈ (5 dem-adv, 7 dem-pron), auto (3 dem-adv, 3 dem-pron) jmt. Kõiki selliseid substantiive ühendab see, et nende tõlgendamine ruumi või mitteruumina sõltub kasutussituatsioonist ning kõneleja individuaalsetest kasutuseelistustest, kusjuures ruumina tõlgendamise võimalus võib esineda ka demonstratiivpronoomeniga konstruktsioonides (vrd näiteid 20 ja 21).

(20) ei julge mõeldagi, mis oleks saanud, kui Richard ei oleks sealt autost välja suutnud ronida (segakategooria: asi, dem-adv)

(21) ka tolles autos oli kogu neljaliikmeline seltskond purjus. (segakategooria: asi, dem-pron) 
Eelnevas alapeatükis vaatasime näiteid, milles abstraktse mittekohasõnaga (st ajale) viitamisel kasutatakse demonstratiivpronoomeniga konstruktsiooni (sellel aastal näites 16). Ajaväljendi ja demonstratiivpronoomeni (eelkõige too) seost on varemgi kirjeldatud (Pajusalu 2017a: 572). Ehkki selle artikli eesmärkide seas ei ole demonstratiivide see ja too kasutuserinevuste selgitamist, väärib eraldi tähelepanu tõsiasi, et ajaväljendiga seostub tugevalt just demonstratiivpronoomen too: 236-st ajasõnaga konstruktsioonist 162-s esines just too.

Teiste mittekohtade juures on demonstratiivpronoomen too suhteliselt tavaline ka siis, kui viidatakse inimeste ühendusele: $17 \mathrm{NP}-\mathrm{d}$ määratlejaga see ja $16 \mathrm{NP}-\mathrm{d}$ määratlejaga too. Elusolendile viitavate substantiividega NP-des (kokku 146) esineb enamasti pronoomen see (117 kasutusjuhtu), too on kasutusalalt kitsam (29 esinemist).

Demonstratiivpronoomen on ka segakategooria abstraktsete substantiivide eelistatum määratleja, mistõttu näib, et selliseidki substantiive mõistestatakse pigem mittekohana (näited 22, 23 ja 24).

(22) oleks igati teretulnud, kui lapsevanematena saaksite neid informeerida sellest võimalusest. (abstraktne, segakategooria: muu, dem-pron)

(23) Seadsin eesmärgiks anda sellesse diskursusesse oma panus. (abstraktne, segakategooria: muu, dem-pron)

(24) Või ei julgeta sellesse ärisse siseneda, et korralik konkurents tekitada. (abstraktne, segakategooria: muu, dem-pron)

Ei saa aga mainimata jätta, et mõnevõrra ootamatu meie tulemuste valguses on tõsiasi, et andmestikus oli kasutatud rohkem demonstratiivadverbiga konstruktsiooni siin elus (6 korda, näide 25) kui -pronoomeniga selles elus (3 korda, 26). Nimelt on elu märgendatud kui abstraktne, segakategooriasse kuuluv substantiiv, millega oleks ootuspärane pigem demonstratiivpronoomeni kasutus. Võimalik, et elu märgendamine semantilisse klassi „muu“ ei ole õigustatud ning elu kasutusi saaks paremini selgitada mingi sellise semantilise kategooria abil, mida meie uurimusse ei ole kaasatud. On ka võimalik, et üheksa NP-d substantiiviga elu on liiga kesine hulk selleks, et põhjapanevaid järeldusi teha. Sellised näited kinnitavad ka seda, et siinse andmestiku põhjal esile tulevad tendentsid ei ole universaalsed, mistõttu oleks tarvis täiendavaid uurimusi. 
(25) Ühel hetkel küsime endalt, mis on minu elu mõte ja eesmärk, mis on minu ülesanne siin elus? (abstraktne, segakategooria: muu, dem-adv)

(26) aga kuidagi raske on jutustada sellest elust, mille sees oled. (abstraktne, segakategooria: muu, dem-pron)

\section{Arutelu ja kokkuvõte}

Artiklis analüüsisime eesti keele kohakäänetes esinevaid kahesõnalisi nimisõnafraase, milles kasutati määratlejana demonstratiivi: kas demonstratiivadverbi (siin, seal, nt siin majas) või demonstratiivpronoomenit (see, too, nt selles majas). Ehkki need konstruktsioonid näivad sarnased, oleme artiklis püstitanud hüpoteesi, et demonstratiivadverbiga konstruktsioonid on seotud pigem ruumilise tähendusega ning -pronoomeniga konstruktsioonides saab referent pigem mitteruumilise tõlgenduse. Võtsime aluseks põhimõtte, et keeles ei esine täielikult sünonüümseid konstruktsioone, st kui näeme erinevusi vormi tasandil, siis tuleks otsida erinevusi ka tähenduse ja funktsiooni tasandilt. Artikli tulemused aitavad selgitada, milliste vahendite abil saavad eesti keele viitavad nimisõnafraasid väljendada seda, kas viidatavat referenti tuleks tõlgendada ruumi või mitteruumina.

Analüüsitav keeleandmestik on Sketch Engine'i abil kogutud 2017. aasta eesti keele ühendkorpusest. Andmestikus on kuue kohakäände kohta kogutud nii demonstratiivadverbide kui ka -pronoomeniga näitelaused. Iga konstruktsioonivariandi kohta on 100 lauset, kokku on andmestikus 2400 lauset. Andmestikus märgendasime kolm tunnust: substantiivi semantiline klass, substantiivi konkreetsus ning konstruktsiooniga koos esineva verbi tüüp. Andmeanalüüsiks kasutasime mitteparameetriliste testidena klassifitseerimispuud ja juhumetsa, mis võimaldavad näha seoseid mitme kategoriaalse tunnuse vahel. Andmestiku põhjal saab teha järeldusi vaid iga alamkonstruktsiooni kasutuskontekstide suhtes, mitte aga iga konkreetse konstruktsiooni esinemissageduse kohta.

Analüüsi tulemused kinnitasid hüpoteesi, et määratleja valik on seotud substantiivi semantilise klassiga, st kohatähenduses substantiiviga esineb sagedamini demonstratiivadverb, mittekoha tähenduses (eelkõige elusolendile ja ajale viitava) substantiiviga kasutatakse määratlejana aga demonstratiivpronoomenit. Lisaks substantiivi 
semantilisele klassile osutus oluliseks määratleja valikut selgitavaks tunnuseks substantiivi konkreetsus. Konkreetse peasõna korral on sagedasem demonstratiivadverb, abstraktse peasõnaga koos esineb rohkem demonstratiivpronoomen. Kusjuures oluline on ka semantilise klassi ja konkreetsuse koosmõju: kui kohale viitamisel on nii abstraktse kui ka konkreetse substantiiviga määratlejana kasutusel üldjuhul demonstratiivadverb, siis abstraktse mittekohasõnaga kasutatakse alati pronoomenikonstruktsiooni (nt sellel ajal), samal ajal kui konkreetse mittekohasõna (nt sellelt arstilt, sinna nõukogusse) korral võib esineda ka demonstratiivadverbiga konstruktsioon. Konstruktsioonis kasutatud verbi tüüp (liikumisverb või mitte) siinses andmestikus statistiliselt oluliseks tunnuseks ei osutunud.

Kirjeldatud suundumused avalduvad eriti selgelt substantiivide puhul, mis kuuluvad juba oma semantiliste omaduste poolest koha või mittekoha hulka. Ent üle poole andmestikus esinenud substantiividest kuulus n-ö segakategooriasse, mida on võimalik tõlgendada nii ruumina kui ka mitteruumina. Siinse uurimuse kontekstis leiame, et just nimelt segakategooria fraaside tõlgendamisel paistab ilmekalt välja määratleja roll ja referentsiaalse potentsiaali realiseerumine keeles. Nimelt, kohta väljendavad substantiivid võimaldavad määratlejaks valida adverbi ehk teisisõnu, adverbiline määratleja saab laiendada vaid kohana mõistetavat substantiivi. Pronominaalsed määratlejad seevastu esinevad koos substantiiviga juhul, kui tuleb tõlgendada mitteruumina.

Ka varasemates uurimustes on näidatud, et eesti keeles võib kohakäänetes teiste vahendite kõrval esineda määratlejana demonstratiivadverb. Siinses töös leidsime, et demonstratiivadverbi määratlejana esinemisel on selged tähenduslikud piirangud. Esiteks, demonstratiivadverbi kasutatakse harva määratlejana siis, kui referendiks on inimene või ajaüksus. Kui selline juhtum esineb, on selle tõlgendus pigem aja ja koha ühtsuses (seal hommikus oli kõik olemas). Demonstratiivadverbi kasutatakse harvemini ka siis, kui tegemist on abstraktse referendiga.

Teiseks, demonstratiivadverb on valdav määratleja, kui substantiiviks on kohasõna. Märgendatud andmestikus esineb konkreetse kohasõnaga viitamisel $80 \%$ juhtudest demonstratiivadverbist määratleja. Nii suur ülekaal võimaldab demonstratiivadverbil toimida kohatähenduse indeksina: kui tõlgendame fraase siin koolis või seal teatris, mis võivad peasõna tähenduse poolest olla kas kohad või institutsioonid, kaldub tõlgendus kohatähenduse poole. Selliselt võimaldavad demonstratiiv- 
adverbid määratlejana eesti keeles anda kohatähenduse varjundi ka sellistele nimisõnadele, millel algselt kohatähendust ei ole (nt seal hommikus).

Lähtusime uurimuses sellest, et dem-pron + NP ja dem-adv + NP on määratlejaga NP alamkonstruktsioonid. Andmeanalüüs lubab kinnitada hüpoteesi paikapidavust: adverbilise ja pronominaalse määratleja süstemaatilised semantilised kasutuserinevused näitavad, et dem-adv + NP ning dem-pron $+\mathrm{NP}$ on referendi definiitsust (identifitseeritavust) markeeriva definiitse määratlejakonstruktsiooni erinevad alamkonstruktsioonid. Eri konstruktsioonidena käsitlemist toetab konstruktsioonigrammatika seisukoht, mille järgi eristab (alam)konstruktsioone teineteisest see, et nende tähendus sarnaneb baastähenduse omaga, kuid lisaks sellele on neil mingi spetsiifilisem konventsionaalne funktsioon (Goldberg 1995, vt ka Penjam 2008: 21-22). Siinses uurimuses vaadeldava põhikonstruktsiooni (määratleja $+\mathrm{NP}$ ) kaks võimalikku alamkonstruktsiooni ${ }^{10}$ on (teiste seas) seega dem-pron + NP ja dem-adv + NP, kus määratleja loob definiitsust/identifitseeritavust. Alamkonstruktsiooni dem-adv + NP peamine lisafunktsioon on seejuures ruumilise referendi taasmainimine, samas kui dem-pron + NP toimib esmajärjekorras mitteruumilise referendi markeerijana.

Demonstratiivadverbide käsitlemine määratlejatena on üldtüpoloogilises plaanis mõneti uudne vaatenurk, sest teiste keelte puhul ei ole demonstratiivadverbe määratlejatena tavaliselt loetletud (vt nt Payne 2006). Näiteks soome keeles on demonstratiivadverbiga konstruktsiooni kirjeldatud kui kinnislisandi (sm kiinteä appositio) konstruktsiooni (ISK 1010-1013). Ka eesti keele uurimisel on esindatud siinsele uurimusele vastandlik seisukoht, et demonstratiive, ei pronominaalseid ega adverbilisi, ei peaks määratlejateks pidama. Näiteks on Sahkai (2003) käsitlenud nimisõnafraasi atribuudina esinevat demonstratiivi hoopis topeldamiskonstruktsioonina, milles referentsiaalset funktsiooni täidab vaid konstruktsiooni substantiivne osis ning provormi peamiseks eesmärgiks on seda leksikaalset fraasi mingil moel esile tõsta. Demonstratiivadverbi pidamine määratlejaks on aga kooskõlas Laury (1996) käsitlusega, milles on adnominaalsetel demonstratiividel just entiteedi mõistestamist toetav roll.

10 Definiitse määratlejaga konstruktsioone on eesti keeles muidki, nt oma + NP, seesama + NP jt, kuid selles uurimuses me neid ei käsitlenud. 
Siinses uurimuses ei ole arvesse võetud kõiki konstruktsiooni kasutust mõjutavaid faktoreid, kuna huvipakkuvaks aspektiks oli vaid määratleja vormi suhe ruumilisuse väljendamisse. Vaadeldavaid alamkonstruktsioone mõjutavate faktorite laiem ülevaade on esitatud Taremaa jt (2021), kus selgus, et lisaks siinses artiklis kirjeldatud faktoritele mõjutab demonstratiivse määratleja valikut näiteks elusus, staatilisus ja teksti formaalsus. Mingi kindla konstruktsiooni esinemine lauses sõltub alati eri faktorite koostoimest (vt nt Klavan, Pilvik \& Uiboaed 2015), kusjuures selle keerukuse taga võib omakorda peituda hoopis muude faktorite mõju (vt sarnast arutlust nt Kibrik 2019).

Näiteid uurides võib tekkida ka õigustatud küsimus, mil määral on määratleja valik seotud üldisemate tunnustega (semantiline klass, konkreetsus) ning millises ulatuses tingib määratleja valikut substantiivi lekseem ise. Näiteks lause 16 (sellel aastal) kohta võib küsida, kas määratleja valikut määravaks põhjuseks on konstruktsiooni mitteruumiline tähendus, ning lause 13 (seal Toompeal) selle ruumiline tähendus, või tingib määratleja valiku hoopis konstruktsioonis esinev substantiiv. Siinses uurimuses kasutatud analüüsimeetod ei võimalda individuaalse lekseemi mõju eraldiseisvalt hinnata, kuid tulevastes uurimustes võiks kasutada analüüsimeetodeid, nt logistilise regressiooni segamudelit, mis võimaldaks võtta arvesse lekseemid kui juhuslikud muutujad (vt nt Klavan, Pilvik \& Uiboaed 2015). Samuti ei saa selle uurimuse valguses öelda, mil määral on adverbiline ja pronominaalne määratleja teineteisega asendatavad ning millistel tingimustel on sobiv vaid emb-kumb määratleja.

Artiklis oleme keskendunud kohasuhete väljendamisele, mistõttu on uurimismaterjalis vaid kohakäänetes nimisõnafraaside näited. Tulemused viitavad sellele, et demonstratiivse määratleja valik ei sõltu konstruktsiooni morfoloogilisest vormist, st mõlemat määratlejat saab kasutada kõikides kohakäänetes. Siiski, kohakäänete ja kohasuhte väljendamise seos ei ole üksühene. Näiteks on Klavan, Alumäe \& Tavast (2020) väliskohakäänete sagedusandmete põhjal näidanud, et kohasuhte väljendamine moodustab ligi $60 \%$ kõikidest ablatiivi kasutusjuhtudest, samas kui adessiivi ja allatiivi puhul jääb kohatähenduste väljendamise osakaal alla viiendiku kõikidest esinemiskordadest (vt väliskohakäänete funktsioone ka EKG I: 58-59, Vainik 1995). Siinkohal ei ole selge, kas võrreldavad tendentsid kehtivad ka sisekohakäänete funktsioonide jaotumisel, ent see on üsna ootuspärane, sest ka väliskohakäänetel on 
lisaks ruumisuhete väljendamisele keeles palju muid ülesandeid (vt sisekohakäänete funktsioone EKG I: 56-58). Ei ole ka selge, kuivõrd esil on ruumitähendus kohakäänete individuaalsetel kasutusjuhtudel. Meie tulemuste valguses näib, et määratleja valik võimaldab kohasuhte funktsiooni intensiivistada, sest adverbilised määratlejad on rohkem seotud ruumi väljendavate substantiividega, pronominaalsed määratlejad aga rohkem mitteruumiliste substantiividega. See muster ei ole absoluutne, vaid paigutub n-ö skaalale, kusjuures variatiivsust lisavad ka veel täiendavad faktorid, nt elusus, temporaalsus, aga ka tekstitüüp (vt lähemalt Taremaa jt: 2021). Lisaks sellele on eesti keeles kohasuhete väljendamiseks võimalik kasutada analüütilisi kaassõnaga konstruktsioone (nt selle laua peale, seal koti sees) (EKG I: 33-34), mille kohta on väidetud, et need on konkreetsema tähendusega ja rõhutavad asukohta rohkem kui kohakäänded (Ojutkangas 2008, Klavan 2012, 2020, Veis-

mann \& Erelt 2017). See, kas adverbilise ja pronominaalse määratleja valik kaassõnafraasidega koos esinedes järgib samu printsiipe mis kohakäänetega, tuleb välja selgitada tulevastes uurimustes.

Uurimuse kokkuvõtteks leiame, et eesti keele demonstratiivsete määratlejate korpuses esinemise seaduspärad lubavad oletada, et nad võivad kohakäändes nimisõnafraasis olla kasutatud referenti looval viisil: kui kasutatakse demonstratiivadverbi, luuakse sellega kohatähendusega referent, kui aga demonstratiivpronoomenit, siis pigem mittekoha tähendusega referent.

\section{Tänuavaldused}

Artikli valmimist on toetanud Euroopa Liidu Regionaalarengu Fond (Eesti-uuringute tippkeskus) ja Eesti Teadusagentuur (PSG671).

\footnotetext{
Allikaviited

Eesti keele ühendkorpus 2017. https://doi.org/10.15155/3-00-0000-0000-0000-071E7L. Sketch Engine. https://www.sketchengine.eu/.
} 
108 Helen Hint, Piia Taremaa, Maria Reile, Renate Pajusalu

\section{Kirjandus}

Abbott, Barbara. 2010. Reference. Oxford: Oxford University Press.

Arppe, Antti. 2009. Linguistic choices vs. probabilities - how much and what can linguistic theory explain? The Fruits of Empirical Linguistics 1. 1-24. https://doi. org/10.1515/9783110216141.1.

Boas, Hans C. 2013. Cognitive construction grammar. Thomas Hoffmann \& Graeme Trousdale (toim.), The Oxford handbook of construction grammar, vol. 1. Oxford/New York: Oxford University Press. https://doi.org/10.1093/oxfor $\mathrm{dhb} / 9780195396683.013 .0013$.

Breiman, Leo. 2001. Random forests. Machine Learning 45(1). 5-32. https://doi. org/10.1023/A:1010933404324.

Cohen, Jacob. 1988. Statistical power analysis for the behavioral sciences, 2nd edn. Hillsdale, NJ: Lawrence Erlbaum Associates.

Croft, William \& Alan D. Cruse. 2004. Cognitive linguistics. Cambridge/New York: Cambridge University Press.

EKG I = Erelt, Mati, Reet Kasik, Helle Metslang, Henno Rajandi, Kristiina Ross, Henn Saari \& Silvi Vare. 1995. Eesti keele grammatika I. Morfoloogia. Sõnamoodustus. Tallinn: Eesti Teaduste Akadeemia Eesti Keele Instituut.

EKSS = Langemets, Margit, Mai Tiits, Tiia Valdre, Leidi Veskis, Ülle Viks \& Piret Voll (toim.). 2009. Eesti keele seletav sõnaraamat I-VI (,,Eesti kirjakeele seletussõnaraamatu“ 2., täiendatud ja parandatud trükk). Tallinn: Eesti Keele Instituut. Eesti Keele Sihtasutus.

Glynn, Dylan \& Justyna A. Robinson (toim.). 2014. Corpus methods for semantics. Quantitative studies in polysemy and synonymy (Human Cognitive Processing 43). Amsterdam: John Benjamins Publishing Company. https://doi.org/10.1075/hcp.43.

Goldberg, Adele E. 1995. Constructions: A construction grammar approach to argument structure. Chicago/London: The University of Chicago Press.

Gries, Stefan Th. 2017. Syntactic alternation research: Taking stock and some suggestions for the future. Belgian Journal of Linguistics 31(1). 8-29. https://doi. org/10.1075/bj1.00001.gri.

Hint, Helen, Tiina Nahkola \& Renate Pajusalu. 2017. With or without articles? A comparison of article-like determiners in Estonian and Finnish. Annekatrin Kaivapalu, Johanna Laakso, Maria-Maren Linkgreim, Raili Pool, Kirsti Siitonen (toim.), Lähivõrdlusi. Lähivertailuja 27, 65-106. http://dx.doi.org/10.5128/LV27.02

Hint, Helen, Maria Reile \& Renate Pajusalu. 2013. Kontekst ja viitamine: argivestlused, legod ja narratiivid. Eesti ja soome-ugri keeleteaduse ajakiri. Journal of Estonian and Finno-Ugric Linguistics 4(1). 161-183. https://doi.org/10.12697/ jeful.2013.4.1.10.

Hoffmann, Thomas \& Graeme Trousdale (toim.). 2013. The Oxford handbook of construction grammar, vol. 1. Oxford/New York: Oxford University Press. https://doi. org/10.1093/oxfordhb/9780195396683.001.0001.

Holmes, Kevin J. \& Phillip Wolff. 2013. Spatial language and the psychological reality of schematization. Cognitive Processing 14(2). 205-208. https://doi.org/10.1007/ s10339-013-0545-5. 
Hothorn, Torsten, Kurt Hornik \& Achim Zeileis. 2006. Unbiased recursive partitioning: A conditional inference framework. Journal of Computational and Graphical Statistics 15(3). 651-674. https://doi.org/10.1198/106186006X133933.

Hothorn, Torsten, Kurt Hornik, Carolin Strobl \& Achim Zeileis. 2021. party: A laboratory for recursive partytioning. https://cran.r-project.org/web/packages/party/index. html.

ISK = Hakulinen, Auli, Maria Vilkuna, Riitta Korhonen, Vesa Koivisto, Tarja-Riitta Heinonen \& Irja Alho. 2004. Iso suomen kielioppi (Suomalaisen Kirjallisuuden Seuran toimituksia 950). Helsinki: Suomalaisen Kirjallisuuden Seura.

Kibrik, Andrej A. 2011. Reference in discourse (Oxford Studies in Typology and Linguistic Theory). Oxford/New York: Oxford University Press.

Kibrik, Andrej A. 2019. Rethinking agreement: Cognition-to-form mapping. Cognitive Linguistics 30(1). 37-83. https://doi.org/10.1515/cog-2017-0035.

Klavan, Jane \& Ann Veismann. 2017. Are corpus-based predictions mirrored in the preferential choices and ratings of native speakers? Predicting the alternation between the Estonian adessive case and the adposition peal 'on'. Eesti ja soomeugri keeleteaduse ajakiri. Journal of Estonian and Finno-Ugric Linguistics 8(2). 59-91. https://doi.org/10.12697/jeful.2017.8.2.03.

Klavan, Jane, Maarja-Liisa Pilvik \& Kristel Uiboaed. 2015. The use of multivariate statistical classification models for predicting constructional choice in spoken, nonstandard varieties of Estonian. SKY Journal of Linguistics 28. 187-224.

Klavan, Jane, Tanel Alumäe \& Arvi Tavast. 2020. Eesti keele väliskohakäänete kasutus poolspontaanses kõnes automaatse transkriptsiooni põhjal. Keel ja Kirjandus 8-9. $757-774$.

Klavan, Jane. 2012. Evidence in linguistics: corpus-linguistic and experimental methods for studying grammatical synonymy (Dissertationes linguisticae Universitatis Tartuensis 15). Tartu: Tartu Ülikooli kirjastus.

Klavan, Jane. 2020. Pitting corpus-based classification models against each other: a case study for predicting constructional choice in written Estonian. Corpus Linguistics and Linguistic Theory 16(2). 363-391. https://doi.org/10.1515/cllt-2016-0010.

Langemets, Margit. 2009. Nimisõna süstemaatiline polüseemia eesti keeles ja selle esitus eesti keelevaras (Tallinna Ülikooli humanitaarteaduste dissertatsioonid 10). Tallinn: Tallinna Ülikool.

Laury, Ritva. 1996. Pronouns and adverbs, figure and ground: The local case forms and locative forms of the Finnish demonstratives in spoken discourse. Timo Haukioja, Marja-Liisa Helasvuo \& Elise Kärkkäinen (toim.), SKY 1996 Yearbook of the Linguistic Association of Finland, 65-92.

Laury, Ritva. 1997. Demonstratives in interaction: the emergence of a definite article in Finnish (Studies in Discourse and Grammar 7). Amsterdam: John Benjamins Publishing Company.

Levinson, Stephen C. 2003. Space in language and cognition: Explorations in cognitive diversity. Cambridge: Cambridge University Press. https://doi.org/10.1017/ CBO9780511613609. 
Lüdecke, Daniel. 2021. sjPlot: Data visualization for statistics in social science. https:// cran.r-project.org/web/packages/sjPlot/index.html.

Ojutkangas, Krista. 2008. Mihin suomessa tarvitaan sisä-grammeja. Virittäjä 112(3). $382-400$.

Pajusalu, Renate. 1997. Is there an article in (spoken) Estonian? Mati Erelt (toim.), Estonian Typological Studies II (Publications of the Department of Estonian of the University of Tartu 8), 146-177. Tartu: Tartu Ülikooli Kirjastus.

Pajusalu, Renate. 2017a. Viiteseosed. Mati Erelt \& Helle Metslang (toim.), Eesti keele süntaks (Eesti keele varamu III), 566-589. Tartu: Tartu Ülikooli Kirjastus.

Pajusalu, Renate. 2017b. Nimisõnafraas. Mati Erelt \& Helle Metslang (toim.), Eesti keele süntaks (Eesti keele varamu III), 379-404. Tartu: Tartu Ülikooli Kirjastus.

Payne, John R. 2006. Noun phrase. Keith Brown (toim.), Encyclopedia of language \& linguistics, 2nd edn., vol. 5, 712-720. Boston: Elsevier Science.

Penjam, Pille. 2008. Eesti kirjakeele da-ja ma-infinitiiviga konstruktsioonid (Dissertationes philologiae estonicae Universitatis Tartuensis 23). Tartu: Tartu Ülikooli Kirjastus.

R Core Team. 2020. R: A Language and Environment for Statistical Computing. Vienna, Austria: R Foundation for Statistical Computing. https://www.r-project.org.

Reile, Maria, Piia Taremaa, Tiina Nahkola \& Renate Pajusalu. 2019. Reference in the borderline of space and discourse: a free production experiment in Estonian, Finnish and Russian. Linguistica Uralica 55(3). 185-208. https://dx.doi.org/10.3176/ lu.2019.3.02.

Ruutma, Mirjam, Aki-Juhani Kyröläinen, Maarja-Liisa Pilvik \& Kristel Uiboaed. 2016. Ambipositsioonide morfosüntaktilise varieerumise kirjeldusi kvantitatiivsete profiilide abil. Keel ja Kirjandus 2. 92-113.

Sahkai, Heete. 2003. Demonstrative doubling in spoken Estonian. Trames 7(2). 120-144.

Siiman, Ann. 2018. Variation of the Estonian singular long and short illative form: A multivariate analysis. SKY Journal of Linguistics 31. 139-167.

Siiman, Ann. 2019. Vormikasutuse varieerumine ning selle põhjused osastava ja sisseütleva käände näitel (Dissertationes philologiae estonicae Universitatis Tartuensis 45). Tartu: Tartu Ülikooli Kirjastus.

Silverstein, Michael. 1976. Shifters, verbal categories, and cultural description. Keith H. Basso \& Henry A. Selby (toim.), Meaning in Anthropology, 11-55. Albuquerque: University of New Mexico Press.

Strobl, Carolin, Anne-Laure Boulesteix, Thomas Kneib, Thomas Augustin \& Achim Zeileis. 2008. Conditional variable importance for random forests. BMC bioinformatics 9. 307. https://doi.org/10.1186/1471-2105-9-307.

Strobl, Carolin, James Malley \& Gerhard Tutz. 2009. An introduction to recursive partitioning: Rationale, application, and characteristics of classification and regression trees, bagging, and random forests. Psychological Methods 14(4). 323-348. https:// doi.org/10.1037/a0016973.

Strobl, Carolin, Torsten Hothorn \& Achim Zeileis. 2009. Party on! The R Journal 1(2). 14-17. https://doi.org/10.32614/RJ-2009-013.

Talmy, Leonard. 2000a. Toward a cognitive semantics. Volume I: Concept structuring systems. Cambridge/London: The MIT Press. 
Talmy, Leonard. 2000b. Toward a cognitive semantics. Volume II: Typology and process in concept structuring. Cambridge/London: The MIT Press.

Taremaa, Piia, Helen Hint, Maria Reile \& Renate Pajusalu. 2021. Constructional variation in Estonian: Demonstrative pronouns and adverbs as determiners in noun phrases. Lingua 254. https://doi.org/10.1016/j.lingua.2021.103030.

Taremaa, Piia. 2017. Lokatiivsete demonstratiivadverbide asetusest ja funktsioonidest liikumist väljendavate klauside näitel. Keel ja Kirjandus 6. 453-468.

Taylor, John R. 1995. Linguistic categorization. Prototypes in linguistic theory. Oxford/ New York: Oxford University Press.

Vainik, Ene. 1995. Eesti keele väliskohakäänete semantika: kognitiivse grammatika vaatenurgast. Tallinn: Eesti Teaduste Akadeemia Eesti Keele Instituut.

Veismann, Ann \& Mati Erelt. 2017. Kaassõnafraas. Mati Erelt \& Helle Metslang (toim.), Eesti keele süntaks (Eesti keele varamu III), 446-462. Tartu: Tartu Ülikooli Kirjastus.

Veismann, Ann, Mati Erelt \& Helle Metslang. 2017. Määrus. Mati Erelt \& Helle Metslang (toim.), Eesti keele süntaks (Eesti keele varamu III), 300-376. Tartu: Tartu Ülikooli Kirjastus.

\begin{abstract}
Helen Hint, Piia Taremaa, Maria Reile, Renate Pajusalu: Demonstrative pronouns and demonstrative adverbs as determiners in Estonian: why are we in "here world" in "this situation"? We investigate the variation of definite determiner constructions in Estonian: noun phrases with a demonstrative pronoun (see 'this', too 'that') or demonstrative adverb (siin 'here', seal 'there') as a determiner are contrasted. The question is what differentiates the use of a demonstrative pronoun and a demonstrative adverb if used in a determiner position in an NP. The data from Estonian National Corpus 2017 were tagged for semantic class of a noun, noun concreteness, and verb type. We collected 100 clauses for each sub-construction (six spatial cases crossed with four determiner forms), 2400 clauses in total. For statistical analysis, we used conditional random forests and inference trees. We show that nouns expressing spatial meaning prefer demonstrative adverbs as determiners, while non-spatial nouns combine with demonstrative pronouns. Spatiality-wise polysemous nouns exhibit more varied preferences. Adverbial determiners are more probably used with concrete nouns, and abstract nouns co-occur with pronominals. Overall, the frequency of demonstrative adverbs as NP attributes confirms that demonstrative adverbs are productive determiners in Estonian.
\end{abstract}

Keywords: demonstrative pronoun, demonstrative adverb, definite determiners, reference, constructional variation, corpus study, Estonian 